\title{
VILJAVUUSANALYYSIN TARKKUUDESTA
}

\author{
Osmo Mäkitie \\ Maatalouden tutkimuskeskus, Maantutkimuslaitos \\ Helsinki
}

Saapunut 1. 3. 1958.

Maan viljavuustutkimuksen tultua yleiseksi on jo nyt suoritettu noin puolen miljoonan maanäytteen helppoliukoisten ravinteiden analysointi, vastaten kahden miljoonan ravinneluvun määrää. Kun viljavuuslukuja käytetään hyväksi jo paitsi käytännön maanviljelyssä, myös mitä erilaisimmissa maahan ja lannoitukseen liittyvissä tutkimuskysymyksissä tilastollisestikin, on paikallaan tarkastella tämän rutiinianalyysin luotettavuutta ja tarkkuutta lähemmin.

Analyysi suoritetaan kaikissa maamme viljavuuslaboratorioissa samaa menetelmää noudattaen (5). Rutiininomaisesti työskentelevissä laitoksissa turvaudutaan sarjatyössä yhteen määrityskertaan, mikä yleensä tavallisessa laboratoriotyössä on poikkeuksellista. Näin ollen ei analyysin tarkkuuden voida odottaakaan olevan suuren, eikä samaa tasoa kuin rinnakkaismäärityksin tarkistettujen analyysien. Järjestelmällinen sarjatyö tuo kuitenkin omat etunsa ja kun työhön liittyy tarkka valvonta ja tarpeelliset tarkistukset, saadaan analyysit näin nopeastikin tehtyinä viljavuustutkimuksen tarkoitusta vastaaviksi.

Puuttumatta varsinaiseen analyysimenetelmään tarkastellaan seuraavassa analyysin virhelähteitä sekä tulosten tarkkuutta ja yhtäpitävyyttä myös eri laboratorioiden kesken.

Näyteaineistona ovat olleet n.s. vertailumaat. Nämä näytteet edustavat eri maalajeja ja viljavuustasoja sekä ovat etukäteen valmiiksi esikäsiteltyjä ja homogenisoituja.

\section{Analyysierän mittaus}

Meikäläinen menetelmä poikkeaa tavallisuudesta siinä, että analyysiin otettava erä maanäytettä mitataan tilavuuseränä. Kun tämä mittaus suoritetaan käsin, n.s. koputussylinterin avulla, vaatii toimitus suorittajaltaan tiettyä harjaantumista ja huolellisuutta. Silti ei tällainen $25 \mathrm{ml}$ :n näyte-erän mittaaminen suju aina virheettömästi, voiden aiheuttaa epävarmuuden jo analyysin alkuvaiheessa. Seuraa- 
vassa esitetään erään kokeen tuloksia koehenkilöiden suoritettua esikäsiteltyjen näytteiden mittaamisen rinnakkaissuorituksina eli rinnakkaisina tilavuuspainomäärityksinä (taul. 1).

Esimerkiksi yhden prosentin virhe kivennäismaan mittauksessa, kun tilavuuspaino on 1.00, aiheuttaa uuttosuhteen muuttumisen 1:10:stä 1.01:10:ksi (tai $0.99: 10: \mathrm{ksi})$. Tämä ero lisää uuttuneita ravinnemääriä keskimäärin seuraavasti; Ca ja $\mathrm{K} \pm 0.95 \%, \mathrm{P} \pm 0.25 \%$ (1). Jos turvemaa on kyseessä (tilavuuspaino esim. $0.25)$, merkitsee vastaavasti yhtäsuuri tilavuuspainon lukuarvon mittausvirhe neljän prosentin virhettä, aiheuttaen e.m. ravinnemäärien erot nelinkertaisina maan painoon verrattuna. Nämä virheet ovat silti mitättömän pienet viljavuustutkimuksessa.

Kun verrataan saman henkilön suorittamia rinnakkaismittauksia keskenään, havaitaan, että keskimääräinen tilavuuspainoero saman henkilön suorittamien määritysten kesken vaihtelee välillä $0.0104-0.0191$ keskiarvon ollessa 0.015 . Tällaista virhettä vastaavat ravinne-erot ovat (tilav.paino 1.00); $\mathrm{Ca}$ ja $\mathrm{K} \pm 1.43 \%$, $\mathrm{P} \pm 0.38 \%$. Eri henkilöiden suorittamien määritysten keskimääräistä tilavuuspainoeroa $0.0225(2.15 \%$ ) vastaavat ravinne-erot ovat; $\mathrm{Ca}$ ja $\mathrm{K} \pm 2.04 \%, \mathrm{P} \pm 0.54 \%$. Koehenkilöiden suorittamien rinnakkaismääritysten vastaava $\mathrm{m}-\%$ on kevyillä mailla $\pm 2.14 \%$, raskailla mailla $\pm 0.95 \%$ eli keskimäärin $\pm 1.38 \%$ tilavuuspainosta (taul. 1).

Taulukko 1. Tilavuuspainomääritysten tarkkuus. Koehenkilöiden A-D suorittamien rinnakkaismääritysten m-\% (á $4 \times 11$ määritystä).

Table 1. The accuracy of volumeweight determinations. The m- $\%$ of volumeweight determination duplicates made by testing persons $A-D$ (a $4 \times 11$ determinations).

A

$\begin{array}{lcccccc} & \text { A } & \text { B } & \text { C } & \text { D } & \text { Keskiarvo } \\ \text { Average } \\ \text { value }\end{array}$

Näytteen »koputtaminen» on henkilökohtainen tottumus ja taito, mikä ei varsin selvästi ilmene suoritetussa kokeessa, missä henkilöt 1 ja 2 ovat tähän työvaiheeseen harjaantuneita, kun taasen henkilöt 3 ja 4 eivät ole olleet jatkuvasti koputusmittausta suorittamassa.

Yleensä on helpompi suorittaa yhteenkäyviä rinnakkaismäärityksiä raskaista kivennäismaista (tilav.paino yli 0.70 ) kuin kevyistä maista. Karkeimmat kivennäismaat ja toisaalta liejupitoiset maat sekä eloperäisten ja kivennäismaitten seokset osoittautuvat vaikeiksi tapauksiksi. Viimemainittuun lienee osaltaan selitys löydettävissä esikäsittelyn homogenisoinnista huolimatta tapahtuvasta näytteen separoitumisesta.

Käsin suoritetun koputuksen tilavuuspainot ovat pienempiä kuin aikaisemmin käytössä olleella koneellisella koputusmenetelmällä saadut arvot. Maantutkimuslaitoksessa on todettu suhdeluvuksi $94.31 \%$ koneellisesta koputuksesta. Vas- 
taavat luvut ovat eri maalajiryhmille; karkeille kivennäismaille $94.92 \%$, savimaille $93.79 \%$ ja turvenaille $95.96 \%$. Hienojakoisissa maissa menetelmien välinen ero on siis suurin.

\section{Viliavuustutkimuksen rutiinimääritysten tarkkuus}

Menetelmän mukainen huiskutus eli ravinteiden uuttaminen maanäytteestä ei ole herkkä virheille, mikä pätee erikoisesti fosfaattien uuttumisen suhteen (1). Virheet muodostuvat useimmiten määritysvaiheissa.

Viljavuustutkimuksen kaikki määritykset perustuvat vertailuun. Maauutetta verrataan tunnettuun, tarkasti tehtyyn vertailuliuokseen kojeellisesti. pH-määrityksissä sekä kalsiumin ja kaliumin liekkifotometrisissa määrityksissä ei työssä ole mitään uuteliuoksen ja reagenssien tilavuuserien mittauksiakaan, kuten on laita kolorimetrisissa fosforimäärityksissä. Ilmenevät virheet aiheutuvat etupäässä kojeiden epäherkkyydestä sekä kojeolosuhteiden muutoksista näytteen ja vertailuliuosten mittausten välillä.

Taulukko 2. Viljavuustutkimuksen rutiinianalyysin tarkkuus.

Table 2. The accuracy of routine soil testing analysis.

\begin{tabular}{|c|c|c|c|c|c|c|c|c|}
\hline & Koe & LU & $\mathrm{Ca}$ & & $\mathbf{K}$ & & $\mathrm{P}$ & \\
\hline & Test & pri & $\mathrm{mg} / 1$ & $\begin{array}{l}\mathrm{Caj} \\
\mathrm{tn} / \mathrm{ha}\end{array}$ & $\mathrm{mg} / \mathrm{l}$ & $\begin{array}{c}\mathrm{K} 40 \\
\mathrm{~kg} / \mathrm{ha}\end{array}$ & $\mathrm{mg} / \mathrm{l}$ & $\begin{array}{c}\text { Psf } \\
\mathrm{kg} / \mathrm{ha}\end{array}$ \\
\hline $\begin{array}{l}\text { Määritysten keskimääräinen } \\
\text { standardipoikkeama }( \pm) \ldots\end{array}$ & A & 0.127 & 10.8 & 0.54 & 3.09 & 189.3 & 0.097 & 22.2 \\
\hline $\begin{array}{l}\text { Av. standard deviation of determi- } \\
\text { nations }( \pm)\end{array}$ & B & 0.119 & 15.0 & 0.75 & 1.92 & 117.2 & 0.145 & 32.6 \\
\hline $\begin{array}{l}\text { Keskimäärin }( \pm) \\
\text { Average }\end{array}$ & & 0.122 & 13.5 & 0.68 & 2.34 & 143.0 & 0.128 & 28.9 \\
\hline Keskimääräinen variatioker- & & & & & & & & \\
\hline roin $( \pm)$ & A & $2.40 \%$ & 8.99 & $\%$ & 7.91 & $\%$ & 9.53 & $\%$ \\
\hline Av, variation coefficient $( \pm)$ & B & $2.08 \%$ & 8.03 & $\%$ & 6.96 & $\%$ & 10.11 & $\%$ \\
\hline $\begin{array}{l}\text { Keskimäärin }( \pm) \\
\text { Average }\end{array}$ & & $2.19 \%$ & 8.37 & $\%$ & 7.30 & $\%$ & 9.90 & $\%$ \\
\hline voille*) $( \pm)$ & & & 5.86 & $\%$ & $7.20^{\circ}$ & & 9.68 & $\%$ \\
\hline $\begin{array}{l}\text { Variation coefficient for practical } \\
\text { values } *)\end{array}$ & & & & & & & & \\
\hline
\end{tabular}

Taulukossa 2 on esitetty kahden eri aineiston tulokset; $A=5$ anal. $\times 10$ näytettä, $\mathrm{B}=5$ anal. $\times 18$ näytettä. $\mathrm{pH}$-määritysten tarkkuus on laskettu prosentteina pH-luvuista 3.9-6.6 (keskiarvo 5.62). pH-määritysten standardipoikkeama \pm 0.122 on varsin pieni kun otetaan huomioon, että maan vesisuspension $\mathrm{pH}$-arvoa ei ole syytä ilmoittaakaan yhtä desimaalia tarkempana $\mathrm{pH}$-arvona.

Liekkifotometrisen kalsiumimäärityksen poikkeaminen kemiallisesta saostamismenetelmästä on keskimäärin $\pm 4.6 \%(4)$.

Kaliumin ja fosforin määrityksissä ei määritystapa eikä kojeisto ole tavallisesti kyllin herkkä, kun halutaan käyttää samaa työmenettelyä ja kojeasteikkoa 
käsittämään kaikki ravinnetasot, aivan pienistä ylirunsaisiin ravinnemääriin saakka.

Rutiinianalyysissä on määritysvirhe alle $10 \%$ oikeista ravinnemääristä. Suurimmat prosentuaaliset virheet esiintyvät ravinneköyhissä maissa. Keskimääräistä viljavuutta edustavissa maissa on tarkkuus keskiarvoja huomattavasti suurempi.

\section{Määritystarkkuus eri laboratorioitten kesken}

Eri laboratorioitten analyysitason tarkistamisessa käytettyjen vertailunäytteiden määrityksistä maamme viljavuustutkimuslaboratorioissa on käytettävissä kaksi aineistoa; $\mathrm{I}=18$ näytettä ja II $=10$ näytettä. Ensimmäiseen vertailuun osallistui 5 laitosta (3) ja toiseen 10 eli kaikki viljavuustutkimuksia nykyisin suorittavat laboratoriot (2). Näiden tutkimusten analyysitarkkuus on esitetty taulukossa 3.

Taulukko 3. Analyysitarkkuus eri laboratorioitten kesken.

Table 3. The accuracy of analysis between different laboratories.

$\begin{array}{lccccc} & \text { Koe Test } & \mathrm{pH} & \text { Caj tn/ha } & \text { K40 kg/ha } & \text { Psf kg/ha } \\ \text { Standardipoikkeama } & \text { I }( \pm) & 0.224 & 1.90 & 334.4 & 65.4 \\ \text { Standard deviation } & \text { II }( \pm) & 0.127 & 1.51 & 317.4 & 52.1 \\ \quad \text { Keskiarvo - Average } & & 0.173 & 1.69 & 325.5 & 58.4 \\ \text { Variatiokerroin*) } & \text { I }( \pm) & 2.97 \% & 13.65 \% & 14.06 \% & 18.60 \% \\ \text { Variation coefficient* } & \text { II }( \pm) & 2.41 \% & 15.71 \% & 12.74 \% & 18.37 \% \\ \quad \text { Keskiarvo - Average } & & 2.68 \% & 14.73 \% & 13.37 \% & 18.48 \%\end{array}$

*) $\mathrm{Caj}>1.0 \mathrm{kn} / \mathrm{ha}, \mathrm{K} 40>400 \mathrm{~kg} / \mathrm{ha}, \mathrm{Psf}>30 \mathrm{~kg} / \mathrm{ha}$

Analyysivirheiden lisäksi vaikuttavat tulosten vaihtelulaajuuteen kunkin laboratorion omat analyysitasoerot, määrityssovellutusten, kojeistojen sekä käsittelytarkkuuden luonteista riippuen. Tiettyjen laboratorioitten huomattavat virheet koroittavat virheprosentteja kohtuuttomasti. Vertailunäytteiden mahdollinen epähomogeenisuus on voinut olla osaltaan tuloksiin vaikuttamassa.

\section{Yhteenveto}

Viljavuustutkimuksen määrityksen virhe (variatiokerroin) on rutiinianalyyseissä, aivan ravinneköyhiä maita lukuunottamatta keskimäärin; $\mathrm{pH} \pm 2.2 \%$, $\mathrm{Ca} \pm 5.9 \%, \mathrm{~K} \pm 7.2 \%$ ja $\mathrm{P} \pm 9.7 \%$.

Analyysissä aiheutuvat suurimmat virheet määrityskojeiden epäherkkyydestä ja tasoeroista, kun sen sijaan määrityksen esikäsittelyvaiheissa ja uuttamisessa ovat virhemahdollisuudet huomattavasti pienemmät. Kuitenkin on pyrittävä rutiinityössäkin mitä huolellisimpaan työskentelyyn sekä kiinnittämään huomiota työntekijäin taitoon ja huolellisuuteen.

Verrattaessa eri laboratorioitten suorittamia analyysejä keskenään, ovat poikkeamat melko suuret. Myöhempi vertailu osoittaa tosin suuntaa parempaan päin.

Määritystarkkuus täyttää yleensä käytännön viljavuustutkimukselle asetettavat vaatimukset, mutta ei ole rutiinianalyysin luonteesta johtuen täysin tyydyttävä tutkimustyössä. Analyysi vaatii laboratoriotyössä tavanomaisen rinnakkaismäärityksen takaaman varmistamisen, mihin järjestelmään on jo Maantutkimuslaitoksen koekenttä- ym. tutkimusnäytteiden analysoinnissa siirryttykin. 
KIRJALLISUUTTA:

(1) Мйкıтіе, O. 1956. Uuttamisesta viljavuusanalyysissa. Summary: Studies on the acid ammonium acetate extraction method in soil testing. Agrogeol. julk. 66. pp 25.

(2) —1957. Vertailu eri laboratorioitten viljavuusanalyyseistä. Koetoiminta ja Käytäntö, 7-8, 1957.

(3) Vuorinen, J. 1954. Viljavuusanalyysit eri laboratorioissa. Koetoiminta ja Käytäntö, 11.1954.

(4) —— ја Мйкıтıе, O. 1951. On determination of calcium direct from soil extract by means of spectrophotometer with flame attachment. Suomen kemistilehti B.3.7-14.

(5) $\rightarrow$ jа МӓкıтіЕ, O. 1955. The method of soil testing in use in Finland. Selostus: Viljavuustutkimuksen analyysimenetelmästä. Agrogeol. publ. 63. pp 44

\author{
S U M M A R Y : \\ ON THE ACCURACY OF ROUTINE SOIL TESTING ANALYSIS
}

\title{
OSMo МӓкттіЕ
}

Agricultural Research Center, Department of Soil Science, Helsinki

The accuracy of soil testing analysis in routine work, without any control of duplicate determinations, has been investigated.

The soil testing method employed in Finland (acid ammonium acetate, pH 4.65) uses a bulk amount of soil for leaching. Neither this preliminary measurement nor the extraction cause significant disturbing errors (Table 1), but the flamephotometric and colorimetric determinations of nutrients need careful work. In these quick-test determinations it is very necessary to keep the instruments at the right level when comparing sample solutions with standard solutions.

The percentage errors are high, especially in nutritionally poor soils, but they are sufficient for the usual practical cultivation (Tables 2-3). The practical errors in routine soil testing analysis are; $\mathrm{pH}$ $\pm 2.2 \%, \mathrm{Ca} \pm 5.9 \%, \mathrm{~K} \pm \mathbf{7 . 2} \%$ and $\mathrm{P} \pm \mathbf{9 . 7} \%$.

For field experiments and scientific investigations it is necessary to carry out a duplicate determination to get more accurate results. 